\title{
Victorian Reading
}

\section{Citation}

Price, Leah. 2012. Victorian Reading. In The Cambridge History of Victorian Literature, ed. Kate Flint, 34-55. Cambridge: Cambridge University Press.

\section{Published Version}

doi:10.1017/CHOL9780521846257.004

\section{Permanent link}

http://nrs.harvard.edu/urn-3:HUL.InstRepos:13575976

\section{Terms of Use}

This article was downloaded from Harvard University's DASH repository, and is made available under the terms and conditions applicable to Other Posted Material, as set forth at http:// nrs.harvard.edu/urn-3:HUL.InstRepos:dash.current.terms-of-use\#LAA

\section{Share Your Story}

The Harvard community has made this article openly available.

Please share how this access benefits you. Submit a story.

\section{Accessibility}




\section{Cambridge Histories Online}

http://universitypublishingonline.org/cambridge/histories/

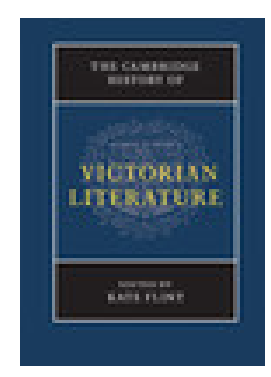

The Cambridge History of Victorian Literature

Edited by Kate Flint

Book DOI: http://dx.doi.org/10.1017/CHOL9780521846257

Online ISBN: 9781139029155

Hardback ISBN: 9780521846257

\section{Chapter}

2 - Victorian reading pp. 34-55

Chapter DOI: http://dx.doi.org/10.1017/CHOL9780521846257.004

Cambridge University Press 


\title{
Victorian reading
}

\author{
LEAH PRICE
}

In I847, Sir Arthur Helps began an essay on reading with the dutiful observation that 'It appears to me remarkable that this subject should have been so little touched upon', but one sometimes feels that the Victorians touched on little else. ${ }^{\mathrm{I}}$ Literacy was credited for reducing criminality and blamed for encouraging sexual licence; the topic fuelled both visual and verbal media, writing and speech. When twenty-first-century scholars gain access to nineteenth-century clichés about reading, they do so via print; but the Victorians themselves used the spoken word to praise writing. Sermons remained the traditional venue for arguments about the benefits and dangers of the printed word, but by the I83os they faced secular competition from after-dinner speeches of benevolent organizations, lectures at the opening of mechanics' institutes, and public addresses like Ruskin's Sesame and Lilies - not to mention Parliamentary debates, themselves transcribed in shorthand and read by many more people than those who had heard them. To read that record now is to remember how many of the policies over which Victorian MPs argued related, directly, or indirectly, to literacy. Schools, libraries, copyright law, postal rates, and above all the taxes that determined the pricing of printed matter: the institutions that the Victorians established, reformed, and attacked were centrally concerned with reading.

This is not to say, of course, that they were concerned specifically with the reading of what we now call 'Victorian literature'. On the one hand, many of the texts composed in this period have had long afterlives, continuing to be reprinted and reread at other times and places. (Until the USA ratified international copyright in I885, much of the audience for British texts was American - if only because the ability to reprint texts originally published in Britain without paying the content provider made them

I Sir Arthur Helps, Friends in Council, 2 vols. (New York: Thomas R. Knox, I847), vol. I, p. 1225 . 
a bargain.) On the other, much of what the Victorians themselves read was written - though less often printed - in earlier centuries. Because copyright priced new texts out of many readers' reach, the steadiest sellers were reference books, reprints, and above all devotional literature. ${ }^{2}$ Even in book form, the British and Foreign Bible Society (jointly founded by Evangelicals and Nonconformists in 1804) was one of the biggest Victorian publishers, while the Society for Promoting Christian Knowledge (its High Church predecessor) was capable of distributing eight million tracts in I867 alone. ${ }^{3}$ At the end of a secularizing century, the Publisher's Circular was still listing more theological works than any other class: 975 religious books in 1880 against 580 novels and 187 books of poetry and drama. ${ }^{4}$ This is not to say that demand corresponded to supply: an I839 survey of $15 \mathrm{I}$ peasant families in Kent found that eighty-six owned a Bible or other religious book, while only eight owned a secular book, ${ }^{5}$ but by the end of the century, fewer than I per cent of loans from public libraries were classified under 'religion'. ${ }^{6}$ This chapter, then, will not focus on the reception of the texts discussed elsewhere in this volume. Rather, it will explore the Victorian theory and practice of reading. What was read in this period, and by whom? What hopes and fears did writers attach to reading (their own and others'), and what vocabulary did they develop to describe - endlessly, ambivalently those textual encounters?

At mid-century, Matthew Arnold declared that 'the main effort, for now many years, has been a critical effort'; $;$ decades later, Oscar Wilde aphorized that 'the highest Criticism deals with art not as expressive but as impressive purely. ${ }^{8}$ Both spoke for a culture in which consumption was upstaging production. (This was not just true for literature: Regenia Gagnier and Paul Saint-Amour have argued that the marginal revolution in economics

2 See William St Clair, 'The Political Economy of Reading', The John Coffin Memorial Lecture in the History of the Book (London: Institute of English Studies, 2005).

3 Richard Altick, The English Common Reader: A Social History of the Mass Reading Public, 1800-1900 (University of Chicago Press, I957), pp. I00-3.

4 Ibid., p. I08. Similarly, the London Catalogue, 1816-1851 lists 10,300 works of divinity against 3,500 of fiction. Charles Knight, The Old Printer and the Modern Press (London: J. Murray, I854), p. 262.

5 David Mitch, The Rise of Popular Literacy in Victorian England (Philadelphia: University of Pennsylvania Press, I992), pp. 44-5.

6 Robert Darnton, 'First Steps toward a History of Reading', in The Kiss of Lamourette: Reflections in Cultural History (New York: Norton, I990), p. I6I.

7 Matthew Arnold, Complete Prose Works, ed. R. H. Super II vols. (Ann Arbor: University of Michigan Press, 1960-77), volume III, p. 258.

8 Oscar Wilde, 'The Critic as Artist', in Plays, Prose Writings and Poems, ed. Isobel Murray (London: J. M. Dent, I975), p. 26. 
provided a model for a new critical interest in the demand side of culture. ${ }^{9}$ ) A century earlier, debates about class crystallized around autodidactic writers like Stephen Duck or Hannah Yearsley; by the time of Victoria's death, in contrast, working-class reading had become a greater subject of concern. Indeed, one might argue that what frightened social thinkers about the expansion of the reading public was precisely the divorce of reading from writing - the growth of a class imagined as passive recipients rather than responsible participants. In the words of the Shakespearean critic Edward Dowden, 'Our caterers nowadays provide us with a mincemeat that needs no chewing, and the teeth of a man may in due time become as obsolete as those which can still be perceived in the foetal whale. ${ }^{\text {Io }}$

That fear may help explain the emphasis in prescriptive literature on the strenuousness of reading, and in particular on the need to link textual consumption to some form of production. Thus Arnold Bennett wrote that real reading required 'more resolution, more pertinacity, and more expenditure of brain-tissue ... It means, in fact, "work" ... I do not think that the literary taste can be satisfactorily formed unless one is prepared to put one's back into the affair.' ${ }^{\text {II }}$ Such advice applied particularly well to women: assumed to be naturally more passive than men, they needed to fight the association of reading with idleness by copying down quotations, indexing favourite passages, summarizing arguments, and (by the end of the century) even taking notes on books to practice their shorthand. ${ }^{\mathrm{I} 2}$ When Lucy Soulsby declared 'I have no faith in reading that is compatible with an arm-chair', ${ }^{13}$ she was privileging those kinds of reading that required a writing-desk over those that manifested neither bodily nor moral backbone.

These debates about women's reading make visible concerns that applied, even if more subtly, to men's as well. One set of values which could be described as 'muscular' - reading instrumentally, generating durable traces of an evanescent activity, marking up the book - constantly clashed with an equally strong desire for receptivity: being absorbed, carried away, marked

9 Regenia Gagnier, The Insatiability of Human Wants: Economics and Aesthetics in Market Society (University of Chicago Press, 2000), p. 4I; Paul K. Saint-Amour, The Copywrights: Intellectual Property and the Literary Imagination (Ithaca, NY: Cornell University Press, 2003), p. 36.

Io Edward Dowden, 'Hopes and Fears for Literature', Fortnightly Review n.s. 45 (I889), pp. $169-70$.

II Arnold Bennett, Literary Taste: How to Form It (London: Hodder and Stoughton, I909), p. 6I.

I2 Kate Flint, The Woman Reader, 1837-1914 (Oxford: Clarendon Press, 1993), p. 95.

I3 Lucy H. M. Soulsby, Stray Thoughts on Reading (London: Longmans Green and Co., I898), p. 6. 
for life by one's reading. What was most often expressed as a difference among audiences (men study, women skim) could also be mapped on to genre: a few standard devotional books were reread 'intensively' (and republished, forming the most profitable part of the backlist), while secular literature in general and novels in particular were read 'extensively. ${ }^{\text {I4 }}$ (Thus, a speech given at the opening of the Kilburn public library - once again, an oral paean to silent reading - pointed out that it was neither 'possible [nor] necessary to read The Proverbs of Solomon and King Solomon's Mines the same way'. ${ }^{15}$ ) As we have seen, the short shelf-life of fiction both caused and reflected the fact that it was rented rather than bought. But the very disposability that made the fortune of circulating libraries worried moralists: could a book that did not stand up to rereading be worth reading at all? According to Herbert Maxwell in I893, 'Unless the recollection of what is read is ensured by notes, reading is a task as fruitless as that of the daughters of Danaus; it serves to spend our limited capital in time without enriching the ever-diminishing store of future. ${ }^{16}$ How could reading (by definition a fleeting experience) continue to yield dividends (in the form of tangible objects)?

The Victorian struggle between active and passive reading has a more concrete consequence for scholars today. Marginalia, valued earlier in the century as proof that reading involved strenuous production rather than idle consumption, was embargoed by the new public libraries, which saw readers' hands as wandering, dirty, or even capable of spreading disease. A side effect was an impoverishment of the evidence available to modern scholars trying to trace the reception of particular texts: since free public libraries tended to order books directly from the publisher rather than inheriting or buying them from an individual collector, and since they so strongly discouraged their own patrons from writing in books, this record of reader response becomes increasingly thin. ${ }^{\mathrm{I}}$

I4 As David Vincent reminds us, intensive and extensive reading inhered in genres more than in individual readers: 'The same reader might now skim a newspaper on his way to work and spend an evening on a single paragraph of a precious book.' David Vincent, The Rise of Mass Literacy: Reading and Writing in Modern Europe (Cambridge: Polity Press, 2000), p. I03.

I5 J. E. C. Weldon, 'The Art of Reading Books', National Review (April I894), pp. 2I3-I8, p. 217.

I6 Herbert Maxwell, 'The Craving for Fiction', Nineteenth Century (June I893), pp. I046-6I, p. 1060.

I7 See H. J. Jackson, Marginalia: Readers Writing in Books (New Haven, CT: Yale University Press, 200I). 
Rules against writing in library books addressed the question of voluntary defacement, but not of involuntary contamination. The second half of the century saw a spate of 'book disinfecting apparatuses', 'metal fumigators', and other inventions designed to disinfect library books after use. Surprisingly, our fullest description of these devices comes from an advocate of free libraries, Thomas Greenwood, who elsewhere urged wealthy collectors to bequeath their books to the public, on the grounds that 'books, like coins, are only performing their right function when they are in circulation' ${ }^{\text {I8 }}$ Just as the marginalia which middle-class men saw as a bulwark against passive reading could look like defacement when practised by women or lower-middle-class library patrons, so the hope that circulation of books would transcend social differences was always haunted by the fear that exchange could contaminate. ${ }^{19}$ As the traditional fear that texts could poison their readers was literalized by the worry that book-objects could spread disease, older concerns about the relation of the reader to a text gave way to newer ones about the relation of one reader to another.

To think about reading, in other words, meant to think about difference between classes, sexes, ages, eras. In Britain, as elsewhere in nineteenthcentury Europe, literacy came to serve as a kind of litmus test for social progress; signatures on marriage registers, statistics about educational level, and examination results of schoolchildren, were all tabulated and correlated with other measures of economic, moral, and medical well-being. (Ironically, as David Vincent points out, statisticians gave far more attention to literacy than they did to the numeracy that made their own enterprise possible. ${ }^{20}$ ) English reformers like G. R. Porter tried in vain to refute the French statistician A. M. Guerry's I833 claim that a rising literacy rate correlated with a rise in crime. The economist W. R. Greg, however, could show only that although high education levels seemed to correlate with a high rate of property crimes, the opposite was true for crimes of violence. ${ }^{2 \mathrm{I}}$ The historian David Vincent has noted the paradox underpinning the foundation of secular national school systems in the nineteenth century: 'If organized religion was the

I8 Thomas Greenwood, Public Libraries: A History of the Movement and a Manual for the Organization and Management of Rate-Supported Libraries (London: Simpkin Marshall, I890), p. 5.

I9 See Lewis C. Roberts, 'Disciplining and Disinfecting Working-Class Readers in the Victorian Public Library', Victorian Literature and Culture 26:I (1998), pp. I05-32; Greenwood, Public Libraries, pp. 494-5.

20 Vincent, Rise of Mass Literacy, p. 5.

2I Patrick Brantlinger, The Reading Lesson: The Threat of Mass Literacy in NineteenthCentury Britain (Bloomington: Indiana University Press, 1998), p. 74. 
intended victim of many literacy campaigns, it managed, at the very least, to bequeath to the secular education process its vocabulary of spiritual reconstruction. ${ }^{22}$

Modern scholars are blessed (and cursed) by the Victorians' own obsession with literacy statistics. Recent estimates lend some support to their triumphalist narrative, charting a jagged climb from a 50 per cent adult literacy rate in 1750 to 95 per cent by $1900 .{ }^{23}$ The overall rise is all the more striking given a temporary dip at the end of the eighteenth century: as the factory system raised the opportunity cost of schooling for children, and as the establishment of new churches and schools failed to keep pace with families migrating to new industrial cities, literacy rates temporarily dropped off. The Industrial Revolution, once seen as the fruit of Enlightenment literacy and numeracy, looked in the short term like their greatest enemy. ${ }^{24}$ Yet in the long run, regional differences in literacy began to flatten - though in the last quarter of the nineteenth century the London area, the far north, and the Channel coast were still more heavily literate. ${ }^{25}$ Gender difference levelled out as well. In I850, 70 per cent of men were measured as literate, against 55 per cent of women; ${ }^{26}$ by the end of the century, though, female literacy rates actually surpassed men's in the rural South and East, where girls were less likely than boys to be withdrawn from school for farm labour. ${ }^{27}$ As literacy became universal, however, it also ceased to become a distinction; literacy made possible geographical mobility from country to city, but social mobility proved more elusive. Biographies and autobiographies represent literacy as the cause of an individual's prosperity, but in hindsight it more often looks like an effect of family income. ${ }^{28}$ The inequalities that literacy was expected to overcome were often ultimately reinforced by it. ${ }^{29}$

The statistics are further complicated by changing measures of what it meant to be literate - including, most basically, whether literacy meant the ability to produce text or to consume it. At the beginning of the century, more people could read than could write - in Webb's estimate, twice or

22 Vincent, Rise of Mass Literacy, p. 22.

23 Mitch, Rise of Popular Literacy, p. xvii; Altick, Common Reader, p. I7I.

24 Vincent, Rise of Mass Literacy, pp. 67-8. 25 Ibid., p. I3.

26 Martyn Lyons, 'New Readers in the Nineteenth Century: Women, Children, Workers', in Guglielmo Cavallo and Roger Chartier (eds.), A History of Reading in the West, (Cambridge: Polity Press, 1999), pp. 313-44: p. 313.

27 Vincent, Rise of Mass Literacy, p. I2. $\quad 28$ Ibid., p. 66.29 Ibid., p. 25. 
three times as many. Even at mid-century, many working-class homes contained printed matter but no writing materials. ${ }^{30}$ But the gap between those skills steadily narrowed, in part because the Revised Code of 1862 stipulated that writing be taught from the beginning, rather than waiting until the child already knew how to read. ${ }^{3 \mathrm{I}}$

Where observers both then and now agree in registering a steady increase in literacy rates, its causes remain more contentious. The growth of a literate population was clearly related - both as effect and as cause - to the steady cheapening of printed matter (always with the exception of the novel): as David Vincent points out, a penny would buy a 250-word broadside in the 1840 , a 7,000 -word songbook by the I860s, a 20,000-word novelette by the $1880 \mathrm{os}$, and by the $1890 \mathrm{os}$ an unabridged version of a classic text. $^{32}$ The Victorians themselves made grand claims for the effects of infrastructures and institutions, like National Schools, public libraries, and the penny post. Recent historians, however, have discounted the importance of successive state interventions in formal education - first subsidies to (I833) and inspections of (I846) church schools, then legislation making elementary education universal (I870), compulsory (I880), and free (I886). ${ }^{33}$ (One reason is that as late as the 1850 s those schools educated only a minority of pupils; when the Education Act passed in 1870, 44,000 London children were still attending dame, private, or ragged schools that received neither subsidy nor inspection. ${ }^{34}$ ) Instead they stress the practical uses that literacy acquired in economic life - or, put the other way around, the rising opportunity cost of not knowing how to read. The ability to fill out printed forms became increasingly crucial to finding (and, though less universally, performing) work. So did the ability to scan printed matter: post-I850 accounts of public libraries suggest that the want ads were among the most heavily used sections of the newspaper. Other historians, however, have stressed that the occupational value of reading deflated as literacy became more universal: in David Vincent's words, 'a determined programme of reading and writing was usually an escape from, rather than an encounter with [people's] struggle to maintain their family economies..$^{35}$

In the last generation before the advent of the radio, leisure, too, was increasingly structured by printed matter. Lyons observes that the first

30 David Vincent, Literacy and Popular Culture: England 1750-1914 (Cambridge University Press, 1989), p. Io.

3I Mitch, Rise of Popular Literacy, pp. 60-I.

32 See Vincent, Literacy and Popular Culture. 33 Vincent, Rise of Mass Literacy, p. 3I.

34 Ibid., p. $34 . \quad 35$ Ibid., p. I47. 
generation to accede to mass literacy 'was also the last to see the book unchallenged as a communications medium'. ${ }^{36}$ David Mitch traces popular literacy to the growth of a national sport network made possible in turn by the growth of railways and telegraphs. Betting spurred on interest in sporting news and sales of newspapers: 'Many a man made the breakthrough to literacy by studying the pages of the One O' Clock [a sporting paper]. ${ }^{37}$ The question of what exactly counted as 'reading' made visible tensions between a rhetoric of moral, economic, or intellectual self-improvement and a reality in which literacy was put to more mundane uses. Thus, Florence Bell remarks that among factory workers, 'About a quarter of the men do not read at all: that is to say, if there is anything coming off in the way of sport that they are interested in, they buy a paper to see the result. That hardly comes under the head of reading. ${ }^{38}$

Periodicals aroused particular anxiety, as a society which ranked books among luxury goods gave way to one in which newspapers came to exemplify both the benefits and the dangers of mass consumption. Opposition to the 'taxes on knowledge' instituted in I8I9 became one of the mainstays of both radical and Liberal politics; in fact, for the early Victorians, questions about the distribution of printed matter were arguably as central to political debate as were longer-lived issues like suffrage and free trade. On the one hand, the hardwon abolition of advertising duties on newspapers (I837), stamp tax (I855), and paper duty (I86I) led to the creation of cheap mass-circulation dailies in place of a split between expensive stamped newspapers and the cheap underground publications produced during the 'war of the unstamped' that lasted between I819 and I836. The result was the rise in the I870s of the New Journalism, which culminated in the first half-penny paper (the Daily Mail, I896) and tabloid (the Daily Mirror, 1903), both founded by Alfred Harmsworth, Lord Northcliffe.

The New Journalism revolutionized mass reading on both sides of the Atlantic: it addressed a new 'half-educated' public by shortening the average article (Tit-Bits, founded in I88I, was often blamed for fragmenting readers' attention spans); stressing human interest (the demise of the guaranteed audience provided by the circulating libraries forced publishers to direct attention to literary authors' private lives, often via the new genre of the

36 Lyons, 'New Readers', p. 313.

37 Quoted in Robert Roberts, The Classic Slum: Salford Life in the First Quarter of the Century (Harmondsworth: Penguin, 1973), p. I64.

38 Florence Eveleen Olliffe Bell, At the Works: A Study of a Manufacturing Town (London: Thomas Nelson, I9II), p. 207. 
interview); ${ }^{39}$ encouraging first-person reports (thus, James Greenwood's Night in a Workhouse (I866) recounted the journalist's own undercover experience, as did W. T. Stead's exposé of child prostitution in the Pall Mall Gazette of I885, 'The Maiden Tribute of Modern Babylon'); and incorporating reader participation. Tit-Bits was especially ingenious, pioneering correspondence columns, treasure hunts, prizes for amateur contributions, and even a life insurance scheme that promised to compensate the next of kin of any commuter found in a railway wreckage with copies of the current week's issue on his person. ${ }^{40}$

The New Journalism partly reflected changes in the technologies by which the news was produced: in the second half of the nineteenth century, the speed with which data was transmitted and the media in which it was represented were transformed by inventions like the electric telegraph, the telephone, the typewriter, the phonograph, the photograph itself, and later the halftone block for photo reproduction. ${ }^{4 \mathrm{I}}$ Less tangible, but equally transformative, were the new price structures enabled by the end of the taxes on knowledge, and new cultural assumptions about the relation of reading to other forms of consumption. As Evelyn March Phillipps complained in I895, 'before long, we shall not be surprised to find even the Times giving away the equivalent for a screw of tea or tobacco with every copy sold'. ${ }^{42}$ The New Journalism substituted bodies for text, in two senses: not only in upstaging reviews of literary works by descriptions of their authors' clothes, homes, and appearance, but also in combining reading with other consumer needs.

The eighteenth century bequeathed to the Victorians an association of mass literacy either with universal enlightenment or with mob rule. On the one hand, the Society for the Diffusion of Useful Knowledge founded by Henry, Lord Brougham in I826 developed new distribution systems for publishing cheap books - and, in commissioning content for publications like Charles Knight's Penny Magazine, to challenge the trickle-down model that for over a century had made cheap books a repository for outdated text

39 'Behind every speech and act there is a man', T. P. O'Connor, 'The New Journalism', New Review I (I889), p. 428. On the interview, see Rosemary Van Arsdel, 'Women's Periodicals and the New Journalism: The Personal Interview', in Joel Weiner (ed.), Papers for the Millions: The New Journalism in Britain (Westport, CT: Greenwood, I988), p. 245.

40 Peter D. McDonald, British Literary Culture and Publishing Practice, 1880-1914 (Cambridge Studies in Publishing and Printing History Index, Cambridge and New York: Cambridge University Press, 1997), pp. I46-9.

4I Joel Wiener, Introduction, Papers for the Millions, p. xii.

42 Evelyn March Phillipps, 'The New Journalism', New Review I (I895), pp. I82-9: p. I82. 
that happened to be in public domain. For early Victorian radicals and reformers, literacy formed at once the cause and the measure of social progress: Bentham was only the most famous author to propose literacy as a criterion for suffrage. According to John Stuart Mill, 'So complete was my father's reliance on the influence of reason over the minds of mankind, whenever it is allowed to teach them, that he felt as if all would be gained if the whole population were taught to read. ${ }^{.43}$ As late as 1902, Lord Avebury could still revive those pieties in his address to the annual meeting of the National Home Reading Union - an organization that encouraged people without much formal education to form reading circles to improve their taste: 'If people realised the intense enjoyment of reading, there would be very little pauperism, extravagance, drunkenness, and crime. ${ }^{44}$ Here again, reading could be praised most effusively in a speech.

On the other hand, the fear of mass literacy remained acute even as its targets shifted, from the Newgate novels of the I830s to the New Journalism of the I890s. In I807 Samuel Whitbread's bill guaranteeing two years of free education to poor children was defeated on the grounds that educating the poor would 'teach them to despise their lot in life' by 'enabl[ing] them to read seditious pamphlets, vicious books, and publications against Christianity'. ${ }^{45}$ In New Grub Street (I89I), George Gissing still worried that literary production was now catering to the 'quarter-educated'. Between those two moments, the imitative theory of the dangers of reading may be best exemplified by Harrison Ainsworth's Newgate novel Jack Sheppard (I839), whose highwayman hero was widely blamed for corrupting its readers.

Put simply, literacy provoked ambivalence. Even staunch Liberals could use ambiguous language, like the double entendre in G. M. Trevelyan's remark that 'Since we have given everyone the key to the house of knowledge, we must show them the door. ${ }^{46}$ And as Patrick Brantlinger has shown, a contrast between virtuous illiterates like Joe Gargery or Mr Boffin and treacherous upwardly mobile readers like Bradley Headstone, Silas Wegg, or Pip directly contradicts Dickens's oft-stated faith in the moral value of education. Victorian ambivalence about reading makes it crucial not to

43 John Stuart Mill, Autobiography (Oxford University Press, 1924), p. 89.

44 Lord Avebury (Sir John Lubbock) at a meeting of the Home Reading Union, 27 February 1902, quoted in Frank Herbert Hayward, The Reform of Moral and Biblical Education (London: S. Sonnenscheim, 1902), p. I43.

45 J. L. Hammond, Barbara Bradby Hammond, and John Christopher Lovell, The Town Labourer (London and New York: Longman, 1978), p. 49.

46 G. M. Trevelyan, 'The White Peril', The Nineteenth Century and After 50 (1901), pp. 1043-55: p. 1052. 
flatten out the different venues in which quotable remarks for or against it appeared. Kate Flint shows, for example, that women's reading was celebrated in particular genres (autobiography, for example) at the very moment when concern was being expressed about it in others (medical manuals and conduct literature) ${ }^{47}$

Conservative critics attacked not just popular literacy itself, but the faith of middle-class intellectuals like Lord Avebury in the mechanical act of running one's eyes along the page. Francis Hitchman was hardly exaggerating when he observed in 1890 that

There are not a few good people in whose eyes in a book is a species of Fetish, and who look upon printed paper with as much reverence as do the Mahometans. To all such the boy who, in their own phrase, 'never has a book out of his hands', is worthy of respect and even of admiration. Unfortunately, however, the lad of this type revels in a literature which is not precisely of the kind of which Cobbett and Franklin hoarded their pence. ${ }^{48}$

Hitchman may have been right to charge that reformers confused the means with the end. By equating (free-thinking?) idealists who saw reading as a panacea with (Mahometan) materialists who worship paper, he satirized the formalism that made reading a good in itself. Similarly, Florence Bell stresses that

learning to read does not necessarily lead to the enjoyment of literature. It is, no doubt, an absolutely necessary step in that direction, but I cannot help thinking, on looking at the results all around, and not only among the workmen, that all knowledge and practice of reading make nearly as often for waste of time as for edification ... The spread of education has a broad back. It is made to bear the burden of many unrealized, if not unrealizable projects. ${ }^{49}$

What commentators disagreed about was not simply the moral consequences of working-class reading, but also how closely they resembled the effects of reading within the social class to which those commentators themselves belonged. Reading was credited (and blamed) with the power both to divide and to unite. When Trollope wrote that 'Novels are in the hands of us all; from the Prime Minister down to the last-appointed scullery-maid', he was celebrating the same fact that Alfred Austin deplored when he wrote

Patrick Brantlinger, The Reading Lesson: The Threat of Mass Literacy in NineteenthCentury Britain (Bloomington: Indiana University Press, 1998), p. 5. Flint, Woman Reader, throughout.

48 Francis Hitchman, 'Penny Fiction', Quarterly Review I7I (1890), pp. I50-7I, p. I5I.

49 Bell, At the Works, p. 204. 
in I870 that 'unhappily, the sensation novel is that one touch of anything but nature that makes the kitchen and the drawing-room kin'. ${ }^{50}$ In theory, shared books cut across social class - whether for good or for evil, as when an I868 cartoon in Punch showed a maid borrowing a lodger's sensation novel. ${ }^{5 \mathrm{I}}$ In practice, as later historians have stressed, a single text could be read in widely differing material forms (circulating-library triple-decker, cheap reprint, pirated abridgment) and adopted by equally divergent interpretive schemes.

In fact, even the same copy of a book could mean different things depending on where it was read - schoolroom or church, parlour or bedroom, pub or railway carriage - and how it was read: silently or aloud, communally or privately. The two don't always align in this period: railways (unlike coaches) enabled silent reading in public spaces, and indeed it was precisely when crammed together with strangers that individuals hid behind unfurled newspapers and absorbing books. While writers and illustrators continued to idealize the image of a father reading a Bible to his family around the hearth, less traditional models of reading aloud were coming to compete: the Chartist declaiming a newspaper in a pub, or - in a riposte to the trope of the selfless daughter reading to the aged and infirm - Rhoda Broughton's satirical representation of a rakish father forcing his daughter to read Parisian feuilletons to him. ${ }^{52}$ The growing opposition between books marketed for collective reading at home and for individual use in public - on the one hand, the 'Railway Libraries' founded in the I840s and the Tauchnitz series of English-language books marketed to travellers on the continent; on the other, series with names like 'Parlour Library' and magazines called Household Words or Family Paper - simplified a reality in which members of the same family might read different books side by side in the parlour, while the same newspapers that commuters used to carve out privacy were sold by the cries of newsboys, read aloud and passed around from hand to hand. ${ }^{53}$

The Victorians imagined themselves - whether for good or ill - to be more thickly enmeshed in communication at a distance than any previous

50 Anthony Trollope, 'The Higher Education of Women', in Morris L. Parrish (ed.), Four Lectures, (London: Constable and Co., 1938), p. 108; [Alfred Austin], 'Our Novels: The Sensational School', Temple Bar (July I870), pp. 4IO-24: p. 424.

5I Flint, Woman Reader, p. 279.

52 Rhoda Broughton, Second Thoughts, 2 vols. (London: Richard Bentley, I880), vol. I, pp. 95-8.

53 Tony Davies, 'Transports of Pleasure: Fiction and Its Audiences in the Later Nineteenth Century', in Formations of Pleasure (London and Boston: Routledge \& Kegan Paul, 1983), p. 49. 
era: together, literacy rates and communications infrastructures defined their modernity. Thus, Thomas Hardy set Far from the Madding Crowd in 'a modern Wessex of railways, the penny post ... labourers who could read and write, and National school children ${ }^{54}$ and Disraeli summed the nineteenth century up as an age of 'railroads, telegraphs, penny posts and penny newspapers. ${ }^{55}$ Indeed, The Times fiction reviewer E. S. Dallas refused to grant the invention of printing any more cultural importance than recent communications technologies: 'the railway and the steamship, the telegraph and the penny postage ... have enormously increased the number of readers, have of themselves created a literature'. ${ }^{56}$ And comparisons could range across place as well as time: although Britain still lagged behind the Scandinavian countries in literacy rates, for example, its postal system handled more letters per capita than any country in Europe. Between I876 and I9I3, the British postal system processed more items per capita than any other country in Europe. $^{57}$

This emphasis on material infrastructures should not seem entirely foreign to literary critics today, because nineteenth-century Britain incubated many of the institutions and technologies that now structure our own reading. We inherit its inventions (the mass-circulation daily newspaper, the advertising circular, the index card); our own content flows through the distribution channels that the Victorians created, from the most utopian (the public library) to the most mundane (the pillar box) - 'libraries' and 'mail boxes' being terms that have readily been borrowed for the virtual capacities of the internet.

What died with the Victorians, however, was a sense that those last two categories were interconnected: that the humblest material contingencies of governing the circulation of ideas could themselves embody political idealism. In I834, on reading a Times report of a speech given in Edinburgh the night before, Lord Cockburn remained silent about the content of Brougham's oratory. Instead, his diary pointed out the purely external fact that the newspaper postdated the speech by only twelve hours: 'post-horses, macadam roads, shorthand and steam-printing never did more' ${ }^{58}$ Like the

54 Thomas Hardy, Preface to I9I2 Wessex edition, Far from the Madding Crowd (London: Penguin, 2003), p. 392.

55 Altick, Common Reader, p. 2 Io.

56 E. S. Dallas, The Gay Science, 2 vols. (London: Chapman and Hall, I866), vol. II, p. 3I2.

57 Vincent, Rise of Mass Literacy, p. I9.

58 Journal of Henry, Lord Cockburn, 1831-42, 2 vols. (Edinburgh: Edmonston and Douglas, I874), vol. I, p. 68. 
'lucifer matches' that Hardy used to symbolize enlightenment, macadam roads emblematized the march of mind, not just of horses: even a worker at the Fernside Paper Mills could remark in a prize essay that 'Cheap literature' has 'opened, and as it were, macadamized a people's road to learning'. ${ }^{59}$ In Matthew Arnold's satire of this logic

Your middle-class man thinks it the highest pitch of development and civilisation when his letters are carried twelve times a day from Islington to Camberwell, and from Camberwell to Islington, and if railway-trains run to and fro between them every quarter of an hour. He thinks it nothing that the trains only carry him from an illiberal, dismal life at Islington to an illiberal, dismal life at Camberwell; and the letters only tell him that such is the life there. ${ }^{60}$

Arnold was right to point to the gap between the lofty claims made for the act of reading and the vulgar practicality of most of what was being read. In any history of literature, it is worth remembering how small a place those texts that we would now call literary occupied in the Victorian printed output. Simon Eliot has calculated that according to the 1907 Census of Production in Britain,

books were worth some $\mathrm{I} 4 \%$ of the total value of print production (and that included manuscript books and ledgers). The two areas of largest value were ... jobbing printing and periodical printing. The most common reading experience, by the mid-nineteenth century at latest, would most likely be the advertising poster, all the tickets, handbills and forms generated by an industrial society, and the daily or weekly paper. ${ }^{6 \mathrm{r}}$

One reason for this is that new commercial genres - the advertising circular, the bulk mailing - were created in response to the expansion and streamlining of the postal system, beginning with the establishment of the penny post in I840. Early Victorian reformers like Rowland Hill denounced a society in which postage rates sundered families, deadened trade, and silenced ideas; in which correspondence was prohibitively expensive for the masses (who therefore had less incentive to learn writing) but free for those few who had personal connections to a MP willing to abuse the privilege of franking (that

59 Andrew King and John Plunkett (eds.), Popular Print Media, 1820-1900, 3 vols. (London; New York: Routledge, 2004), vol. III, p. 4.

60 Arnold, Complete Prose Works, vol. v, pp. 2I-2.

6I Simon Eliot, 'The Reading Experience Database; or, What Are We to Do About the History of Reading?' online document, The Reading Experience Database 1450-1945, www.open.ac.uk/Arts/RED/redback.htm, accessed i5 June 2010. 
is, sending letters for free); in which postage on letters had to be paid by the recipient, while prepayment was available only for printed matter. The government stamp that newspapers required until I855 constituted a form at once of taxation, of censorship (since it priced political news too high for working-class readers), and of prepayment: for the flat fee incorporated into the original purchase price, it entitled newspapers to be circulated and recirculated without charge to the recipient. In I838, the Select Committee on Postage drew attention to the frauds encouraged by the gap between the high price of sending personal letters and the free circulation of stamped newspapers: 'the present existing practice of corresponding through the medium of newspapers, viz. by means of conventional forms in the address, marks under the print, concealed writing on the margin or wrapper, and other contrivances, to which the high rates of postage have given birth' ${ }^{62}$ Another unintended consequence of the stamp tax was that inflated prices forced workers to club together to buy newspapers: reading thus came to look like an occasion for oral debate and collective action.

Today, we take for granted two of the basic features of the postal system established from I839 onwards: prepayment by the sender and rates standardized for anywhere within the nation, regardless of distance. The reformers didn't simply standardize across distances, however, but also across classes: in the process, they destroyed the monopoly on free postage held by MPs - who had routinely lent their franking privileges as part of an economy of favours. When Harriet Martineau exulted that 'tradesmen's and artizans' families can at last write to one another as if they were all MPs', she equated correspondence with political power. The result was a shift (in one scholar's words) from the post conceived as 'a taxable privilege giving access to the public sphere' to the post as 'a public service for private individuals, ${ }^{63}$

Some of the postal reformers' hopes proved justified. With the introduction of prepaid penny postage, later followed by the adhesive stamp and the pillar box, the volume of letters sent through the post increased dramatically. Although much of this expansion took the form of commercial correspondence and advertising, radicals tended to emphasize instead the moral benefits of personal letters: most commonly invoked was the Pamela-esque scenario

62 'A Report of the Select Committee on Postage', Fraser's Magazine I8 (I838), pp. 250-2: p. 252.

63 Mary Favret, Romantic Correspondence: Women, Politics, and the Fiction of Letters (Cambridge University Press, 1993), p. 204. 
of a child in service in London being rescued from vice by the letters of a parent in their village. Thus, Rowland Hill's pamphlet Post Office Reform: Its Importance and Practicality (1837) quotes letters by middle-class observers that describe labourers spurred by cheap postage to learn to write - though not, strikingly, the labourers' letters themselves. Rowland Hill quoted evidence that 'The consequence of high rates, in preventing the workingclass from having intercourse by letter, is, that those who learned at school to write a copy have lost their ability to do so. ${ }^{64}$ Literacy figured in his writings not simply as an end in itself, however, but also as a means to morality more generally. Thus, Hill quoted an employer testifying that 'I have seen much of the evils resulting from want of communication between parents and their children among the young persons in our establishment; I find the want of communication with their parents by letter has led, in some instances, to vice and profligacy which might have been otherwise prevented. ${ }^{65}$ Meanwhile, a member of the Statistical Department of the Board of Trade speculated that 'many young persons of both sexes, who are continually drawn to this metropolis from distant parts of the kingdom, and are thenceforth cut off from communication with their early guardians, might under different circumstances, be kept from entering on vicious courses'. ${ }^{6}$ Yet cheap postage was thought to encourage labour mobility as well: one petition for repeal of the stamp tax argued that cheap newspapers would allow workers to know when and where our labour is likely to bear a fair price ... If compelled to leave the country of our birth, we wd fain know in what land our labour is in demand, and not, as too many have done, strew with our bones an inhospitable soil. ${ }^{167}$ The Select Committee on Postage heard 'evidence to show that the difficulty of communication aggravated "The remarkable pertinacity of the poor to continue in their own parish, rather than remove to another where their condition would be bettered"' 68 The new labour force, then, was imagined as physically portable but morally anchored by family correspondences.

Where printed books are concerned, however, the most important Victorian innovation was probably not the postal system but the circulating

64 Rowland Hill and George Birkbeck Norman Hill, The Life of Sir Rowland Hill ... And the History of Penny Postage, 2 vols. (London: Thos. De La Rue, I880), vol. I, p. 309.

65 Ibid., p. 308.

66 Sir Rowland Hill, Post Office Reform, Its Importance and Practicability (London: C. Knight and Co., I837), p. 78.

67 Dobson Collet, History of the Taxes on Knowledge, 2 vols. (London: T. Fisher Unwin, I899), vol. I, p. 84 .

68 Hill, Life, vol. I, p. 309. 
library. While some genres (such as reference books and devotional books) were bought more often than borrowed, others (notably the novel) found their most reliable distribution channel not through the bookseller but through the library. The Public Libraries Act of 1850 spurred the foundation of free lending libraries in many towns, but equally important was the foundation eight years earlier of Mudie's Circulating Library. Private lending libraries had been common enough in the eighteenth century, when recent fiction already made up most of their stock, but the circulating library became even more attractive after price increases in the i8ros placed the novel - now almost invariably published in three volumes at a guinea and a half - out of reach of most individual buyers. Not only was the new novel more expensive both than reprints of older fiction and than poetry (at about a fifth of the price), it was also the most ephemeral of genres, dominated by best-sellers that quickly faded from view rather than by a durable backlist. It therefore made cultural as well as economic sense to borrow novels rather than buying them: on the one hand, Mudie's yearly fee was less than the cost of a single novel; on the other, novels appeared to have more in common with newspapers - to be read on first appearance and then forgotten - than with either poetry (made for rereading and display) or steady sellers (Bibles, cookbooks, reference works). To its defenders, the novel looked timely and topical; to its critics, ephemeral and modish. Both perceptions formed at once the cause and the effect of a cycle in which a successful novel would trickle down a series of formats: serialization in a magazine or independent part issue, usually running for a year and a half; library-issue triple-decker at a guinea and a half; a six-shilling one-volume reprint a few years later; and eventual oblivion, sometimes pulping.

Everywhere, the novel's ephemerality made its users unwilling to pay higher prices; but where in the United States the result was disposable books, cheaply produced for a single reading, in Britain novels were expensively produced in order to stand up to multiple borrowings. It is worth remembering that the Victorians leased many kinds of objects, not just novels: even furniture was commonly rented in the age before instalment plans, credit cards, and widely diffused mortgage lending. ${ }^{69}$ But Charles Edward Mudie was the first bookseller to take this principle to its logical conclusion. From New Oxford Street, he delivered throughout London by

69 Simon Eliot, 'The Business of Victorian Publishing', in Deirdre David (ed.), The Cambridge Companion to the Victorian Novel (Cambridge University Press, 200I), pp. 37-6o: p. 39. 
van and throughout Britain by rail, eventually devising a system for shipping books abroad in tin boxes. By 1863 Mudie's offered a million volumes, leading one writer in the Spectator to miscalculate that it was 'larger than the Bodleian or the Vatican library'. ${ }^{\circ}$ The only real competition came from the railway circulating libraries established in 1860 by W. H. Smith, the booksellers who pioneered the distribution of printed matter along the fifteen thousand miles of track laid between I 840 and I 870 - first by channelling newspapers and other periodicals outward from London, then by opening bookstalls in railway stations (starting in 1848 and rising to over a thousand branches by the turn of the century), and in 1860 by opening a rival to Mudie's consisting of circulating library branches set up in railway stations.

Smith's shared Mudie's double function: a distribution network, but also a gatekeeper. Mudie took the adjective in 'Select Library' very literally, refusing to stock books that struck him as irreligious, immoral, or even simply indelicate. Since the circulating libraries provided both dependable and substantial sales (half the first edition of Great Expectations, for example, was bought by Mudie's, as were half of the 4,000 novels published by Bentley in 1864) they shaped not just the consumption but also the production of novels, determining what publishers would accept and, indirectly, what novelists would submit. ${ }^{7 \mathrm{I}}$

While this influence has usually been framed in negative terms - and Mudie's certainly did create a kind of self-censorship - it should also be acknowledged that the existence of a stable market for new fiction was part of what drove the great flowering of the Victorian novel in general, and of domestic fiction in particular. Wyndham Lewis may have had a point when he credited Mudie's, tongue in cheek, with instilling in 'the British middleclass mind those few ideas it possesses' ${ }^{72}$ In particular, because young girls were considered at once the largest and most susceptible segment of the novel-reading public, a hypothetical girl became the lowest common denominator against whose supposed sensitivities every new publication was measured. As Dickens complained in Our Mutual Friend,

The question about everything was, would it bring a blush into the cheek of the young person? And the inconvenience of the young person was that ... she seemed always liable to burst into blushes when there was no need at

70 Guinevere Griest, Mudie's Circulating Library and the Victorian Novel (Bloomington: Indiana University Press, 1970), p. 28.

7I John Sutherland, Victorian Fiction: Writers, Publishers, Readers (Basingstoke: Palgrave, 2006).

72 Griest, Mudie's Circulating Library, p. 223. 
all ... There appeared to be no line of demarcation between the young person's excessive innocence, and another person's guiltiest knowledge ... The soberest tints of drab, white, lilac, and grey, were all flaming red to this troublesome Bull of a young person. ${ }^{73}$

When Eliza Lynn Linton argued that every house should contain a 'locked bookcase', or when Thomas Hardy speculated that the demise of the circulating library would make books 'naturally resolve themselves into classes instead of being, as now, made to wear a common livery in style and subject', ${ }^{74}$ both were protesting the unintended consequences of a century-old rehabilitation campaign. Hardy was responding in part to Mudie's refusal to stock Jude the Obscure; similarly, Mudie's rejection of George Moore's A Modern Lover (I883) inspired Moore's Literature at Nurse, or Circulating Morals (1885), which called the 'British matron' Mudie's nom de plume. Such polemics, however, had little effect on the power of circulating libraries. Rather, Mudie's and W. H. Smith committed commercial suicide when in 1894 they informed publishers that they would now pay a maximum of four shillings per volume. In the wake of that decision, a single six-shilling volume became the standard format for new fiction, and buying replaced borrowing.

The Victorians associated modernity not just with an excess of readers, but also with an excess of print. In fact, the statistics about the number of new readers mirrored equally oft-cited calculations about the number of new books. For decades, alarmists continued to reprint a chart showing that as many books were published in I868 alone as in the first half of the eighteenth century. ${ }^{75}$ The same held true for raw material: paper production went from 2500 tons in 1715 to 75000 tons in I85I; measured per person, production shot up from two and a half pounds per year in 1800 to eight and a half in I860. In I893, Herbert Maxwell contrasted 'the number of books that a single bookworm' could consume (9,000, in his estimate) with the number produced (20,000 annually added 'to the shelves of the British Museum'). ${ }^{76}$

Part of the problem was that newspapers proliferated after abolition of the taxes on knowledge. Ephemeral forms were blamed for crowding

73 Charles Dickens, Our Mutual Friend (1864-5; Oxford University Press, 2009), chapter II, pp. I29-30.

74 Eliza Lynn Linton, 'Candour in English Fiction', New Review 2 (I890), pp. I0-I4: p. I3; Thomas Hardy, 'Candour in English Fiction', New Review 2 (I890), pp. I5-2I: p. 2I.

75 Joseph Ackland, 'Elementary Education and the Decay of Literature', Nineteenth Century 35 (I894), pp. 4I6-I8.

76 Herbert Maxwell, 'The Craving for Fiction', Nineteenth Century 33 (I893), pp. I046-6I. 
out more durable classics: 'at the end of the year [The Times] is comprised in a book larger than all the classics and all the standard histories of the world put together'. ${ }^{77}$ Yet the problem became recursive, since newspapers and magazines themselves were padded out with hackneyed statistics about the number of newspapers and magazines. As a journalist observed in $\mathrm{I} 862$,

There are persons who will count up the number of acres which a single number of the Times would cover if all the copies were spread out flat, or illustrate the number of copies by telling us how long the same weight of coal would serve an ordinary household ... Every morning, it is said, a mass of print, containing as much matter as a thick octavo volume, is laid on our breakfast-tables. ${ }^{78}$

Indeed, the Pall Mall Gazette proposed marking Victoria’s Jubilee by a year in which 'the literary soil should be allowed to lie fallow', with an embargo on the production of new literature - except, of course, for newspapers. ${ }^{79}$

Readers had to cope not only with new material, however, but also with the survival of older books and the reprinting of older texts. In the Malthusian reasoning of one reviewer, 'the fire-proof inventions of the present day' had the unintended consequence of ensuring that 'there is no epidemic among books ... no law of mortality by which the number of books is regulated like that of animals' ${ }^{80}$ The result, as Frederic Harrison saw it, was that 'the first intellectual task of our age is rightly to order and make serviceable the vast realm of printed material which four centuries have swept across our path'. ${ }^{8 \mathrm{I}}$ And his contemporaries did in fact rise to that task, in the form of collective projects like the Oxford English Dictionary and the Dictionary of National Biography. The most characteristic genre of the nineteenth century may not, in the end, be the novel or even the newspaper so much as the reference book.

The Victorians, in short, were discovering information overload. Maria Jane Jewsbury described hers as 'an age of books! Of book making! Book

77 Unsigned review, 'Journalism', Cornhill Magazine 3I (I862), pp. 52-63.

78 Ibid., p. 60.

79 Pall Mall Gazette (I2 January I886), p. 4; Kelly J. Mays, 'The Disease of Reading and Victorian Periodicals', in John O. Jordan and Robert L. Patten (eds.), Literature in the Marketplace: Nineteenth-Century British Reading and Publishing Practices (Cambridge University Press, 1995), pp. I65-94: p. I89.

80 Unsigned review, 'The Encyclopedia Britannica', Quarterly Review 70 (1842), pp. 44-72.

8I Frederic Harrison, The Choice of Books, and Other Literary Pieces (London: Macmillan, I886), p. I8. 
reading! Book reviewing! And book forgetting. ${ }^{, 82}$ 'The difficulty of finding something to read in an age when half the world is engaged in writing books for the other half to read is not one of quantity', noted one journalist in I893, 'so that the question, "What shall I read?" inevitably suggests the parallel query, "What shall I not read?" 83 In The Choice of Books, Harrison, too, presented the problem in negative terms: 'the most useful help to reading is to know what we should not read, what we can keep out from that small cleared spot in the overgrown jungle of "information", 84

On the one hand, there was the hope that the spread of literacy would perfect civilization; on the other, the fear that the spread of print would destroy it. As George Craik remarked in his classic compendium of exemplary biographies, The Pursuit of Knowledge Under Difficulties, 'If one mind be in danger of starving for want of books, another may be surfeited by too many. ${ }^{85}$ A decade later, an article in the Victoria Magazine presented these problems as mirror images: 'Of the underfed, in these days of education of women, education of ploughboys, education of curates, we are sure to hear enough, but of the sufferings of their scarcely less pitiable antipodes, whose complaint is overfeeding, we are not so likely to be well informed. ${ }^{86}$

Printed attacks on printed matter always risk self-referentiality, if not quixotism. 'We find the "Quarterly Review" anathematising circulating libraries with great force', notes an I87I article on 'Circulating Libraries', but 'this is very hard on libraries now-a-days, especially as no inconsiderable number of the "Quarterly Review" is taken in by Mr Mudie'. ${ }^{87}$ Conductbooks remarked that trashy reading took time away from outdoor activity, but neglected to count the hours eaten up by their own perusal. Some genres circumvented this problem by distinguishing the readers discussed from the readers addressed: thus, men were instructed on how to control their daughters' reading, or middle-class philanthropists informed about the reading habits of mechanics. In obscenity trials, too, middle-class male jurors were asked to speculate about the effects of a book on their housemaid.

82 Lucy Newlyn, Reading, Writing, and Romanticism: The Anxiety of Reception (Oxford University Press, 2000), p. 3.

83 Unsigned article, 'A Few Words About Reading', Chamber's Journal of Popular Literature, Science, and Arts 70 (1893), pp. 225-7.

84 Harrison, Choice of Books, p. 3.

85 George L. Craik, The Pursuit of Knowledge under Difficulties, new edn, 2 vols. (London: J. Murray, I858), vol. I, p. 22.

86 C. H. Butterworth, 'Reading, Overfeeding', Victoria Magazine I4 (I869-70), pp. 500-4: p. 500.

87 Hain Friswell, 'Circulating Libraries', London Society 20 (I87I), pp. 5I5-24: p. 5I9. 
But even the addressee of a proto-sociological tract rarely maintained complete distance from the styles of reading under discussion. When Florence Bell set out to survey the reading habits of a manufacturing town in I9II, she ended up turning her sociological gaze back on her own readers: 'On finding what were the results of the inquiry made respecting reading among the workmen, a similar investigation was attempted among people who were better off, and the result of this inquiry among those whom we may call "drawing-room readers" is curiously instructive. ${ }^{.88}$ If reading (in Austin's words) made kitchen and drawing-room kin, so did discourses about reading. The fears and fantasies that Victorian intellectuals attached to literacy refracted their own entanglement in the world of print.

88 Bell, At the Works, p. 250. 